CZASOPISMO INŻYNIERII LADDOWEJ, ŚRODOWISKA I ARCHITEKTURY

JOURNAL OF CIVIL ENGINEERING, ENVIRONMENT AND ARCHITECTURE

JCEEA, t. XXXII, z. 62 (4/15), październik-grudzień 2015, s. 73-92

\author{
Marian GIŻEJOWSKI ${ }^{1}$ \\ Radosław SZCZERBA ${ }^{2}$ \\ Marcin GAJEWSKI ${ }^{3}$ \\ Zbigniew STACHURA ${ }^{4}$
}

\title{
ANALIZA NOŚNOŚCI STALOWEJ RAMY PLASKIEJ O BLACHOWNICOWYCH ELEMENTACH SMUKŁOŚCIENNYCH
}

\begin{abstract}
W pracy przedstawiono analizę nośności stalowej ramy płaskiej na przykładzie ramy portalowej o rozpiętości 36,0 m, wykonanej ze smukłościennych elementów blachownicowych o zmiennej wysokości środnika i przegubowo połączonej $\mathrm{z}$ fundamentami. Ramę portalową zaprojektowano zgodnie z wymaganiami Eurokodu, a następnie przeanalizowano wpływ rozmieszczenia dyskretnych stężeń bocznych i przeciwskrętnych na jej nośność. Obliczenia uwzględniają imperfekcje konstrukcji, które zaimplementowano w modelu jako przeskalowane formy wyboczenia lokalnego i globalnego ramy portalowej, wyznaczone ze sprężystej analizy wyboczeniowej LBA. W celu zbadania wpływu rodzaju i kształtu imperfekcji na nośność ramy, przeprowadzono najpierw analizę układu o geometrii idealnej, materiałowo i geometrycznie nieliniową GMNA, a następnie analizę materiałowo i geometrycznie nieliniową GMNIA układu imperfekcyjnego. Analizę przeprowadzono $\mathrm{z}$ wykorzystaniem programu komputerowego ABAQUS/Standard. $\mathrm{W}$ uwagach końcowych podsumowano wyniki analiz oraz wskazano kierunki dalszych badań.
\end{abstract}

Słowa kluczowe: rama portalowa, blachownicowe elementy stalowe, stateczność, imperfekcje, LBA, GMNA, GMNIA

\footnotetext{
${ }^{1}$ Marian Giżejowski, Politechnika Warszawska, al. Armii Ludowej 16, 00-637 Warszawa, tel.: +48 22234 6554, m.gizejowski@il.pw.edu.pl.

2 Autor do korespondencji: Radosław Szczerba, Politechnika Rzeszowska, ul. Poznańska 2, 35-084 Rzeszów, tel.: +48 1786516 16, szczerba@prz.edu.pl.

${ }^{3}$ Marcin Gajewski, Politechnika Warszawska, al. Armii Ludowej 16, 00-637 Warszawa, tel.: +48 22234 5164, m.gajewski@il.pw.edu.pl.

${ }^{4}$ Zbigniew Stachura, Politechnika Warszawska, al. Armii Ludowej 16, 00-637 Warszawa, tel.: +48 22234 6554, z.stachura@il.pw.edu.pl.
} 


\section{Wprowadzenie}

Ustroje poprzeczne budynków halowych bardzo często kształtuje się $\mathrm{z}$ elementów pełnościennych, wykonanych $\mathrm{z}$ dwuteowników walcowanych na gorąco bądź spawanych $\mathrm{z}$ blach. Takie rozwiązanie skutkuje większym zużyciem stali, niż wynika to $\mathrm{z}$ zastosowania dźwigarów kratowych, jednak ze względu na niską pracochłonność w wytwórni konstrukcji metalowych oraz łatwość montażu może prowadzić do obniżenia kosztów całej inwestycji [1]. Słupy układów pełnościennych połączone są z fundamentami w sposób przegubowy, co ułatwia ukształtowanie węzła podporowego, bądź na sztywno w celu ograniczenia nadmiernego bocznego przechyłu ramy ze względu na zachowaniu stanu granicznego użytkowalności. Pręty ram o niedużej rozpiętości wykonuje się z kształtowników dwuteowych gorącowalcowanych, a ram o znacznych rozpiętościach ze spawanych elementów blachownicowych, często o zbieżnej wysokości przekroju ukształtowanej poprzez ciągłą zmianę wysokości środnika. Coraz częściej środniki blachownic wykonuje się z cienkich blach falistych, co prowadzi do polepszenia ich stateczności i poprawienia wartości wskaźnika zużycia stali [2].

Cechą charakterystyczną pełnościennych ram portalowych (jedno- lub wielonawowych) jest sztywne połączenie rygla ze słupem w narożu oraz zazwyczaj sztywne połączenie rygli w kalenicy. W wyniku tego, w narożu ram powstaje duży moment zginający, który determinuje przyjęcie przekrojów rygla oraz słupa. W celu zmniejszenia wymiarów prętów układu w narożu ramy (w węźle okapowym) wykonuje się dodatkowo skosy z ukośnie przyciętego kształtownika o na ogół tym samym przekroju co rygiel. Miejsca występowania ekstremalnych momentów zginających oraz sił osiowych należy odpowiednio stężyć bocznie i przeciwskrętnie $\mathrm{w}$ celu zapewnienia stateczności rygla oraz słupa w strefie ściskanej. Jako dyskretne stężenia boczne wykorzystuje się zwyczajowo prętowe elementy obudowy hal (rygle ścienne i płatwie), które odpowiednio łączy się z pasami rygli oraz słupów, a stosując dodatkowe zastrzały wprowadza się również dyskretne stężenia przeciwskrętne. Na ciągłe stężenie boczne prętów ram można natomiast wykorzystać poszycie z blachy falistej, charakteryzującej się dużą sztywnością podłużną w kierunku prostopadłym do kierunku profilowania blachy oraz znaczną sztywnością giętno-skrętną przy zginaniu $\mathrm{W}$ płaszczyźnie prostopadłej do płaszczyzny zgodnej z kierunkiem profilowania blachy. Węzły w połączeniu podstawy z fundamentem kształtuje się na ogół jako przegubowe, pozostałe zaś węzły (okapowy i kalenicowy) jako sztywne użebrowane. Różne sposoby ukształtowania węzła kalenicowego pokazano na rys. $1[3]$.

W przypadku schematów statycznie niewyznaczalnych można, oprócz globalnej analizy sprężystej, zastosować analizę plastyczną, jeżeli przekroje elementów wykazują wystarczającą zdolność do obrotu wymaganą w celu redystrybucji momentów zginających, a w miejscach powstawania przegubów pla- 
stycznych zapewniona jest stabilność elementów. Zasady kształtowania ram portalowych, a także umiejscowienia stężeń bocznych i przeciwskrętnych w przypadku projektowania sprężystego oraz z wykorzystaniem właściwości plastycznych materiału przedstawiono $\mathrm{w}$ [4].

a)

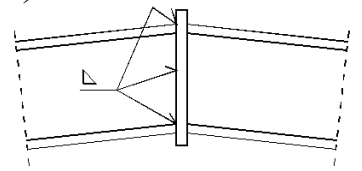

b)

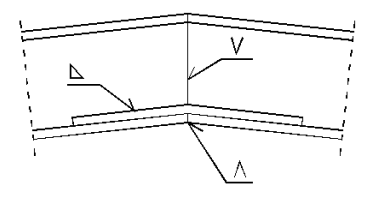

c)

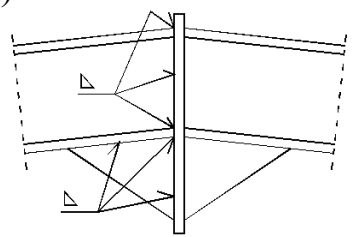

d)

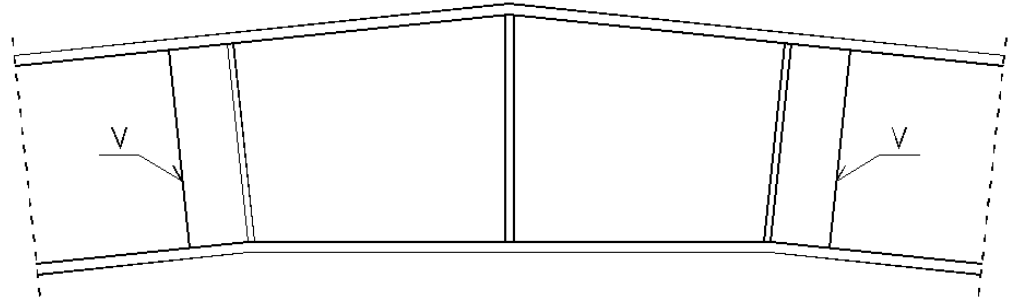

Rys. 1. Możliwe rozwiązania konstrukcyjne spawanego węzła kalenicowego ramy portalowej według [3]

Fig. 1. Possible welded ridge connections of portal frame according to [3]

Zagadnienie przedstawione $\mathrm{w}$ niniejszej pracy dotyczy analizy nośności płaskiej ramy portalowej o rozpiętości $36,0 \mathrm{~m}$, wykonanej ze smukłościennych dwuteowych elementów blachownicowych o zmiennej wysokości środnika na długości rygla i słupów, które są przegubowo oparte na fundamentach. Przeprowadzone obliczenia dotyczą wpływu rozmieszczenia dyskretnych stężeń bocznych i przeciwskrętnych na stateczność globalną ramy i lokalną jej elementów. Nośność ramy sprawdzono na podstawie globalnego kryterium odniesionego do punktu granicznego na ścieżce równowagi wyznaczonej z analiz materiałowo i geometrycznie nieliniowych GMNA (bez uwzględnienia imperfekcji) oraz GMNIA (z uwzględnieniem imperfekcji). Pole imperfekcji geometrycznych zaimplementowane w modelu numerycznym bazuje na postaci deformacji ustroju wyznaczonej ze sprężystej analizy wyboczeniowej LBA. Wpływ kształtu oraz rodzaju imperfekcji na nośność ramy portalowej oceniono porównując mnożniki obciążenia granicznego $\alpha_{u l t}$ wyznaczone najpierw z analizy GMNA dotyczącej ustroju o geometrii idealnej, a następnie z analizy GMNIA ustroju o geometrii nieidealnej. Model MES ramy portalowej wykonano w programie komputerowym ABAQUS/Standard, wykorzystując elementy powłokowe o liniowych funkcjach kształtu. Rozważania w niniejszej pracy są kontynuacją analiz przedstawionych w pracy [5], w której przyjęto prętowy model MES ra- 
my z elementami belkowymi spełniającymi założenia teorii prętów cienkościennych Własowa oraz analizę materiałowo liniową. Rozszerzenie badań przedstawionych $\mathrm{w}$ [5] polega na zastosowaniu nieliniowości materiału oraz przyjęciu powłokowego modelu MES konstrukcji.

\section{Metody weryfikacji nośności ram portalowych}

W przypadku projektowania konstrukcji stalowych dopuszcza się stosowanie sprężystych i niesprężystych metod analizy, które rozróżnia się ze względu na przyjęty model materiału (liniowo-sprężysty, sprężysto-plastyczny, sztywnoplastyczny) oraz rodzaj analizy konstrukcji (wg teorii pierwszego lub drugiego rzędu) $[6,7]$. Wybór metody w konkretnej sytuacji powinien być uzasadniony. Przykładowe ścieżki równowagi statycznej konstrukcji, uzależnione od rodzaju zastosowanej metody analizy układu, przedstawiono na rys. 2. Syntezę podejść możliwych do zastosowania $\mathrm{w}$ praktyce przedstawiono $\mathrm{w}$ tabl. 1 (na podstawie eurokodów [8-11] oraz [12]).

Tabela 1. Rodzaje analiz konstrukcji stalowych według [8-11]

Table 1. Analysis methods of steel structures according to [8-11]

\begin{tabular}{|c|l|c|c|c|}
\hline \multicolumn{2}{|c|}{ Rodzaj analizy } & $\begin{array}{c}\text { Związki } \\
\text { geometryczne }\end{array}$ & $\begin{array}{c}\text { Charakterystyka } \\
\text { materiału }\end{array}$ & $\begin{array}{c}\text { Geometria } \\
\text { układu }\end{array}$ \\
\hline $\mathbf{1}$ & $\begin{array}{l}\text { Analiza liniowo-sprężysta } \\
\text { (LA) }\end{array}$ & liniowe & liniowa & idealna \\
\hline $\mathbf{2}$ & $\begin{array}{l}\text { Liniowo-sprężysta analiza } \\
\text { bifurkacyjna (LBA) }\end{array}$ & liniowe & liniowa & idealna \\
\hline $\mathbf{3}$ & $\begin{array}{l}\text { Geometrycznie nieliniowa } \\
\text { analiza sprężysta (GNA) }\end{array}$ & nieliniowe & liniowa & idealna \\
\hline $\mathbf{4}$ & $\begin{array}{l}\text { Analiza fizycznie nieliniowa } \\
\text { (MNA) }\end{array}$ & liniowe & nieliniowa & idealna \\
\hline $\mathbf{5}$ & $\begin{array}{l}\text { Analiza fizycznie i geome- } \\
\text { trycznie nieliniowa (GMNA) }\end{array}$ & nieliniowe & nieliniowa & idealna \\
\hline $\mathbf{6}$ & $\begin{array}{l}\text { Geometrycznie nieliniowa } \\
\text { analiza sprężysta z imper- } \\
\text { fekcjami (GNIA) }\end{array}$ & nieliniowe & liniowa & nieidealna \\
\hline $\mathbf{7}$ & $\begin{array}{l}\text { Analiza geometrycznie } \\
\text { i fizycznie nieliniowa z im- } \\
\text { perfekcjami (GMNIA) }\end{array}$ & nieliniowe & nieliniowa & nieidealna \\
\hline
\end{tabular}




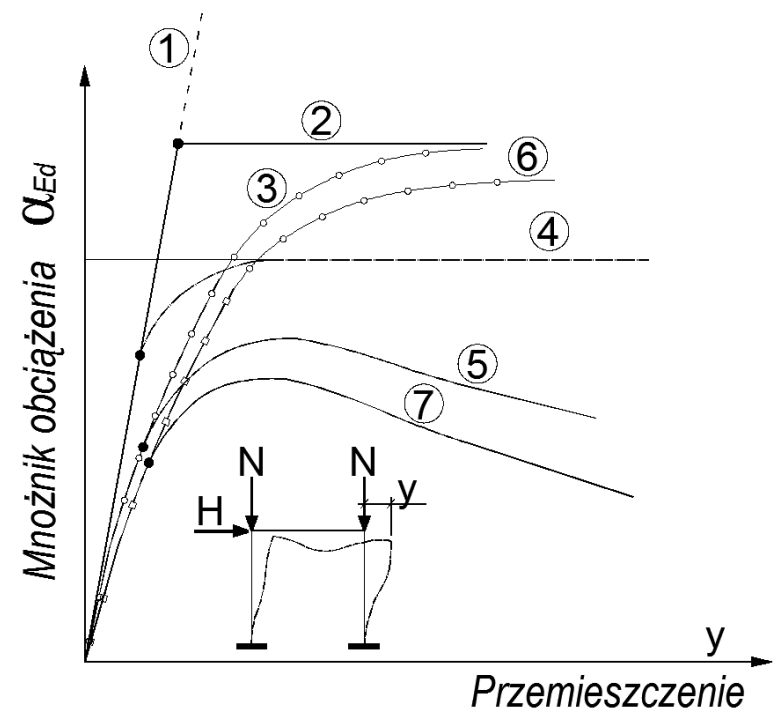

Rys. 2. Ścieżki równowagi statycznej w przypadku zastosowania sprężystych i niesprężystych metod analiz: 1-LA, 2- LBA, 3- GNA, 4- MNA, 5-GMNA, 6- GNIA, 7- GMNIA

Fig. 2. Load-deformation-curves in the case of application of linear and nonlinear analysis methods: 1-LA, 2- LBA, 3- GNA, 4- MNA, 5-GMNA, 6- GNIA, 7- GMNIA

W projektowaniu konstrukcji stalowych należy w ogólności uwzględnić imperfekcje oraz efekty II rzędu, przy czym w Załączniku krajowym normy [8] podano, że w przypadku przechyłowych ram portalowych można stosować w obliczeniach statycznych analizę pierwszego rzędu bez imperfekcji. Weryfikacja nośności słupa bądź rygla pełnościennej ramy portalowej sprowadza się wtedy do analizy pręta ściskanego mimośrodowo i uwzględnienia interakcji niestateczności lokalnej i ogólnej, odpowiadającej formom giętnym oraz giętnoskrętnym.

Ogólne zasady projektowania stalowych układów ramowych podano $\mathrm{w}[1-5]$ oraz $\mathrm{w}[13,14]$. W niniejszej pracy przedstawiono wykorzystanie metod globalnej analizy do oceny nośności ramy portalowej. Przeprowadzono analizy GMNA, w których uwzględniono nieliniowość materiału i efekty II rzędu oraz GMNIA, w których dodatkowo uwzględniono imperfekcje modelowane jako zastępcze parametry bezpieczeństwa i przyjęte jako przeskalowany stan deformacji uzyskany $z$ analizy LBA sprężystego wyboczenia ramy o geometrii idealnej. Według [8], w przypadku analizy GMNA wymagane jest sprawdzenie warunków nośności elementów z uwzględnieniem efektów oddziaływań wyznaczonych dla mnożnika obciążenia $\alpha_{E d}=1$, w przypadku zaś analizy GMNIA nie jest konieczne sprawdzanie stateczności pojedynczych elementów, ale wykazanie, że w punkcie granicznym ścieżki równowagi zachodzi $\alpha_{E d}=\alpha_{u l t} \geq \gamma_{M I}$. 


\section{Charakterystyka analizowanej ramy}

Analizowana rama płaska stanowi poprzeczny układ nośny jednonawowej hali stalowej, o wymiarach rzutu poziomego w osiach słupów 36,0 x 72,0 m (przy rozstawie ram 7,2 m), który zaprojektowano w [5] w stanie sprężystym i przy przyjęciu prętowego modelu konstrukcji. Wysokość ramy wynosi odpowiednio $10,47 \mathrm{~m}$ w okapie i 14,39 m w kalenicy. Nachylenie pasa zewnętrznego dwuspadowego rygla przyjęto jako $12^{\circ}$. Pasy blachownic o przekrojach dwuteowych wykonano z blachy o grubości $18 \mathrm{~mm}$, a środniki z blachy grubości $8 \mathrm{~mm}$. Całkowita wysokość przekrojów w węzłach podporowych $(\mathrm{A}, \mathrm{B})$ oraz w kalenicy (E) wynosi $780 \mathrm{~mm}$, a w narożach ramy (C, D) $1100 \mathrm{~mm}$. Rozstaw płatwi przyjęto jako $2000 \mathrm{~mm}$ (licząc od naroża), a rygli ściennych $1600 \mathrm{~mm}$ (zaczynając od podstawy ramy). W narożach ramy występują trzy obustronne żebra usztywniające gr. $18 \mathrm{~mm}$ (dwa poprzeczne i jedno ukośne), a we wszystkich miejscach oparcia rygli ściennych oraz płatwi na pasie zewnętrznym ramy żebra poprzeczne obustronne gr. $8 \mathrm{~mm}$. W węźle kalenicowym zastosowano rozwiązanie jak na rys. 1d, przy czym żebro ma grubość $18 \mathrm{~mm}$.

We wszystkich miejscach reakcji od rygli obudowy (na pasie zewnętrznym blachownicy słupa ramy) założono występowanie dyskretnych stężeń bocznych. Stężenia przeciwskrętne przyjęto w $1 / 3$ i $2 / 3$ wysokości słupa oraz przy narożu, a także na ryglu pod trzema pierwszymi płatwiami licząc od okapu, a także w kalenicy. Geometrię ramy, wymiary jej przekrojów charakterystycznych oraz usytuowanie stężeń pośrednich przedstawiono na rys. 3. Przyjęto, że rama wykonana jest ze stali konstrukcyjnej S 355 JR.

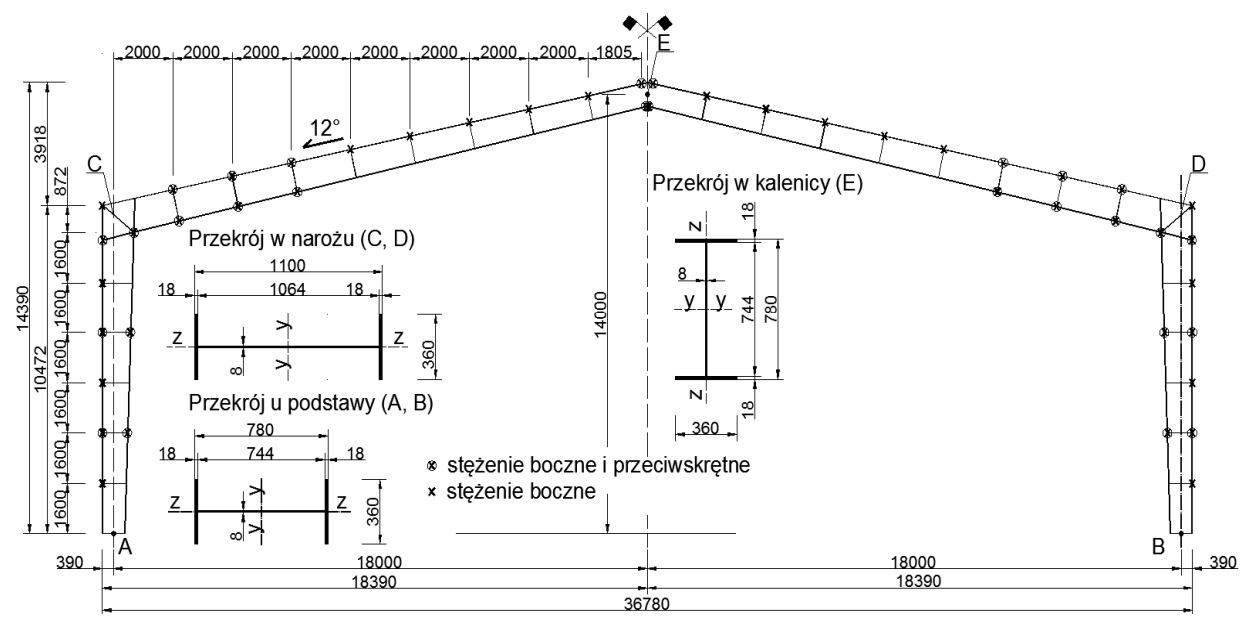

Rys. 3. Wymiary geometryczne, warunki podparcia oraz rozmieszczenie stężeń w ramie portalowej złożonej z elementów blachownicowych o zbieżnym środniku [5]

Fig. 3. Geometry, constraints and location of lateral and torsional braces in analyzed portal frame composed of I-shaped tapered elements [5] 
Budynek halowy zlokalizowany jest w 3. strefie obciążenia śniegiem i w 2. strefie obciążenia wiatrem, w terenie kategorii II (teren otwarty z nielicznymi przeszkodami). Przy projektowaniu wzięto pod uwagę sytuacje trwałe, odnoszące się do zwykłych warunków użytkowania. Nie rozpatrzono wyjątkowych sytuacji obliczeniowych, odnoszących się do pożaru, wybuchu, uderzenia lub konsekwencji lokalnego zniszczenia. Spośród wszystkich kombinacji normowych, w stanie granicznym nośności, wyróżniono dwie kombinacje oddziaływań, determinujące przyjęcie przekrojów prętów ramy portalowej. Rozróżniono je ze względu na charakter oddziaływań wiodących: oddziaływanie śniegu (kombinacja oddziaływań grawitacyjnych KOMB1) oraz wiatru (oddziaływanie wiatru w kierunku podłużnym, powodujące przechył ramy KOMB2) [5]. Miarodajnym do oceny nośności ramy jest wskaźnik wykorzystania nośności obliczony na podstawie efektów oddziaływań $\mathrm{z}$ analizy LA oraz $\mathrm{z}$ uwzględnieniem interakcji wyboczenia z płaszczyzny ramy ze zwichrzeniem słupa BD w przypadku kombinacji oddziaływań grawitacyjnych KOMB 1 . Po przyjęciu $\gamma_{M I}=1,0$ otrzymano [5]:

$$
\begin{aligned}
& \frac{\gamma_{M 1} N_{E d}}{\chi_{z} N_{R k}}+k_{z y} \frac{\gamma_{M 1} M_{y, E d}}{\chi_{L T} M_{y, R k}}= \\
& =\frac{1 \cdot 409 \cdot 10^{3}}{0,874 \cdot 5571 \cdot 10^{3}}+0,997 \frac{1 \cdot 2119,6 \cdot 10^{6}}{0,888 \cdot 2828,3 \cdot 10^{6}}=0,925<1,0 .
\end{aligned}
$$

\section{Powłokowy model numeryczny ramy}

Model MES analizowanej ramy portalowej wykonano z użyciem liniowych, prostokątnych elementów powłokowych typu S4R (ze zredukowanym całkowaniem), dostępnych w bibliotece programu ABAQUS/Standard $[15,16]$. Przeprowadzono analizę zbieżności rozwiązania z uwzględnieniem wpływu dyskretyzacji modelu. Przybliżoną wielkość elementów skończonych uzależniono od wymiarów przekroju blachownic oraz żeber. Siatkę sukcesywnie zagęszczano utrzymując proporcje wymiarów elementów skończonych zbliżone do kwadratu. Przy siatce dyskretyzacyjnej o wymiarze boku elementu $60 \mathrm{~mm}$ otrzymywano dobrą zbieżność wyników przy akceptowalnym czasie obliczeń. Model MES ramy portalowej przedstawiono na rys. 4, gdzie pokazano jeden z możliwych przypadków rozmieszczenia stężeń bocznych i przeciwskrętnych, gdy występują one we wszystkich miejscach występowania rygli ściennych i płatwi dachowych. Warunki brzegowe w przekrojach podporowych, które odpowiadałyby w modelu prętowym tzw. podparciu widełkowemu bez możliwości deplanacji, zadano wprowadzając tzw. węzły odniesienia $R P_{i}(i=A, B)$. Przez „sztywne” powiązanie węzłów krawędziowych elementów powłokowych leżących w przekrojach końcowych słupów z węzłem odniesienia uzyskano możliwość zadawania „prętowych” warunków brzegowych tylko dla tego węzła. Za- 
stosowano w tym celu opcję MPC w programie ABAQUS $[15,16]$. Na rys. 5 przedstawiono sposób modelowania warunków brzegowych, stężeń dyskretnych oraz sposobu przekazywania obciążenia z konstrukcji podpierającej poszycie ścian i dachu. Obciążenie z płatwi i rygli ściennych na ramę zadano jako równomiernie rozłożone na paśmie o szerokości $100 \mathrm{~mm}$.

Warunki przemieszczeniowe realizujące dyskretne stężenia pośrednie zadano jako punktowe $\mathrm{w}$ miejscach połączenia środnika $\mathrm{z}$ pasami ramy. Boczne więzy $\mathrm{u}_{\mathrm{y}}=0$ przyjęto $\mathrm{w}$ punktach od 1 do 32 . Dodatkowe więzy obrotowe $\mathrm{R}_{\mathrm{x}}=0$ założono $\mathrm{w}$ wybranych punktach od 1 do 32 oraz boczne $\mathrm{u}_{\mathrm{y}}=0$ i obrotowe $\mathrm{R}_{\mathrm{x}}=0 \mathrm{w}$ punktach od 33 do 62 odpowiadających wybranym punktom od 1 do 32 tak, aby występowały one po obu stronach połączenia środnika $\mathrm{z}$ pasami. $\mathrm{W}$ tabl. 2 zestawiono analizowane warianty rozmieszczenia dyskretnych stężeń bocznych i przeciwskrętnych w rozpatrywanej ramie portalowej.

Do rozwiązywania zagadnień brzegowych liniowej stateczności sprężystej LBA wykorzystano standardową procedurę wyznaczania wartości i wektorów własnych zaimplementowaną $\mathrm{w}$ programie ABAQUS, do zagadnień natomiast technicznego wyboczenia na podstawie analizy nieliniowej ścieżki równowagi wykorzystano analizy GMNA i GMNIA zaimplementowane w ramach opcji umiarkowanie dużych deformacji NLGEOM [17]. Do opisu charakterystyki $\sigma-\varepsilon$ stali wykorzystano model dwuliniowy materiału sprężysto-idealnieplastycznego.

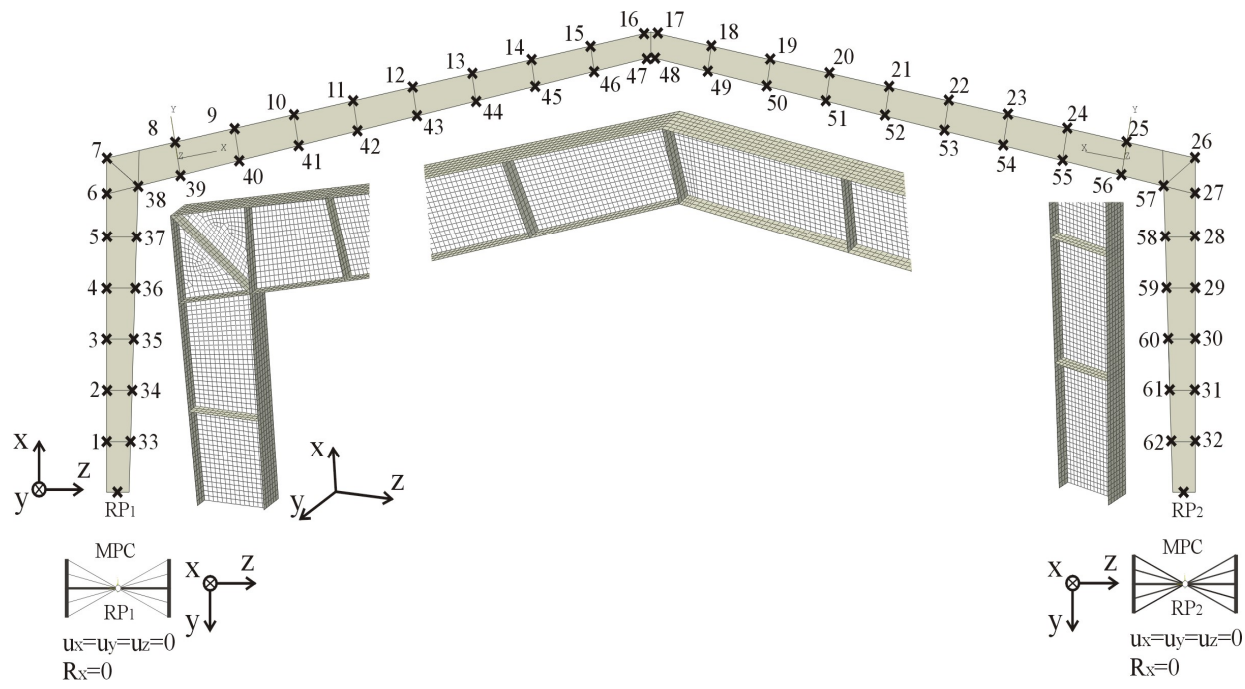

Rys. 4. Powłokowy model MES ramy portalowej wraz z zadanymi warunkami brzegowymi i orientacją w globalnym układzie współrzędnych. Stężenia boczne i przeciwskrętne są modelowane przez dodatkowe więzy, które mogą występować jedynie w punktach od 1 do 62

Fig. 4. FEM model of analyzed portal frame together with boundary conditions and orientation in global coordinate system. Lateral and torsional braces are modelled through additional constraints, which could be located only at points from 1 to 62 
a)

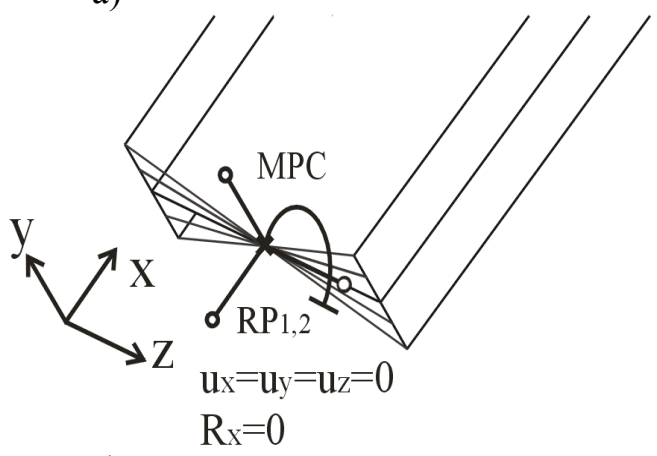

c)

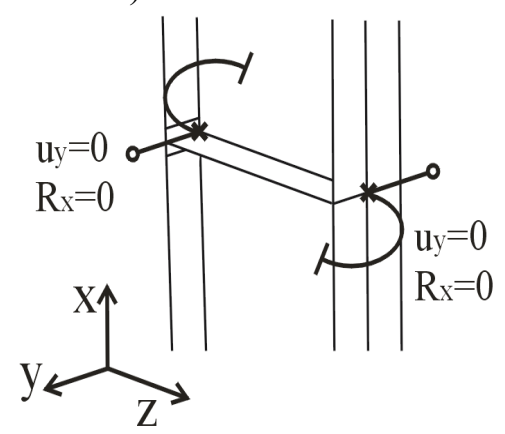

b)

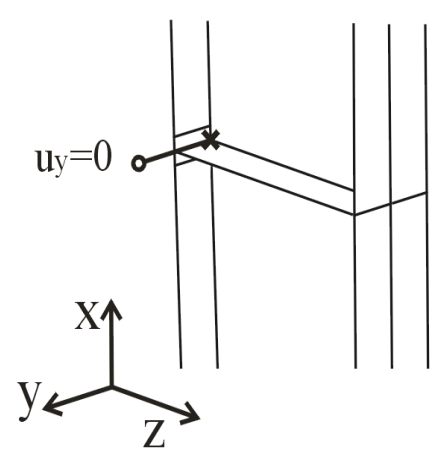

d)

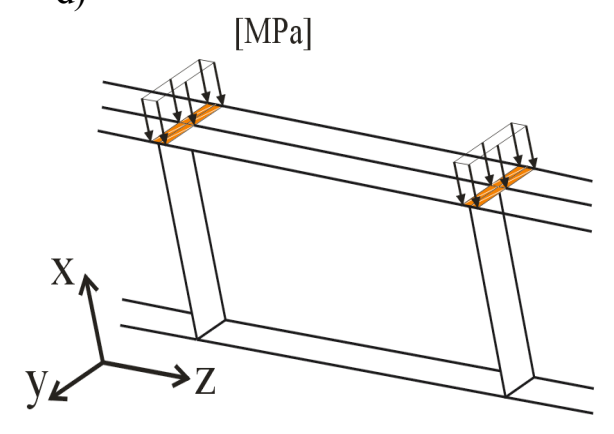

Rys. 5. Warunki brzegowe; a) przemieszczeniowe $u_{x}=u_{y}=u_{z}=0$ i $R_{x}=0$ w przekrojach podporowych (A, B) zadane $\mathrm{z}$ wykorzystaniem opcji MPC, b) warunki przemieszczeniowe $\mathrm{u}_{\mathrm{y}}=0$ (stężenie boczne $\mathrm{w}$ miejscu połączenia środnika $\mathrm{z}$ pasem zewnętrznym blachownicy), c) przemieszczeniowe $\mathrm{u}_{\mathrm{y}}=0$ i $\mathrm{R}_{\mathrm{x}}=0$ (stężenie boczne i przeciwskrętne w miejscach połączenia środnika z pasami), d) obciążenie przekazywane z płatwi i rygli ściennych na ramę (zadano jako powierzchniowe równomiernie rozłożone, na paśmie o szerokości $100 \mathrm{~mm}$ )

Fig. 5. Boundary conditions; a) displacements $u_{x}=u_{y}=u_{z}=0$ and rotation $R_{x}=0$ in base sections (A, B) applied with the use of MPC option, b) displacement $\mathrm{u}_{\mathrm{y}}=0$ (lateral brace located at junction of web and outer flange), c) displacement $u_{y}=0$ and rotation $R_{x}=0$ (lateral and torsional brace located at junction of web and flanges), d) load transmitted from purlins and girts on the frame (uniformly distributed pressure on the $100 \mathrm{~mm}$ wide strip) 
Tabela 2. Warianty rozmieszczenia żeber oraz dyskretnych stężeń bocznych i przeciwskrętnych

Table 2. Location options of transverse stiffeners and lateral and torsional braces

\begin{tabular}{|c|c|c|c|c|c|c|c|}
\hline \multirow{2}{*}{$\begin{array}{c}\text { Wariant } \\
\text { rozmiesz- } \\
\text { czenia } \\
\text { żeber } \\
\text { i stężeń }\end{array}$} & \multicolumn{3}{|c|}{$\begin{array}{l}\text { Obustronne żebra } \\
\text { usztywniające }\end{array}$} & \multicolumn{2}{|c|}{$\begin{array}{c}\text { Stężenia } \\
\text { boczne }\end{array}$} & \multicolumn{2}{|c|}{ Stężenia przeciwskrętne } \\
\hline & $\begin{array}{c}\text { Naroża } \\
\text { ramy } \\
(C, D)\end{array}$ & $\begin{array}{l}\text { Środek } \\
\text { rygla } \\
(\mathrm{E})\end{array}$ & $\begin{array}{l}\text { Pod każdym } \\
\text { stężeniem } \\
\text { przeciwskręt- } \\
\text { nym/ reakcją } \\
\text { od obudowy }\end{array}$ & Słup & Rygiel & Słup & Rygiel \\
\hline $\mathrm{A}$ & \multirow{9}{*}{$\begin{array}{l}3 \text { że- } \\
\text { bra }\end{array}$} & \multirow{9}{*}{$\begin{array}{l}1 \text { że- } \\
\text { bro }\end{array}$} & Tak/Nie & \multirow{9}{*}{\multicolumn{2}{|c|}{$\begin{array}{l}\text { Pod każdym ry- } \\
\text { glem ściennym } \\
\text { i płatwią od stro- } \\
\text { ny } \\
\text { zewnętrznej } \\
\text { i dodatkowo } \\
\text { w miejscu stężeń } \\
\text { przeciwskrętnych }\end{array}$}} & \multirow{2}{*}{$\begin{array}{l}\text { Podstawa } \\
\text { i przy } \\
\text { narożu }\end{array}$} & \multirow[b]{2}{*}{$\begin{array}{l}\text { Przy narożu } \\
\text { i przy węźle } \\
\text { środkowym } \\
\text { rygla } \\
+ \\
\text { pod } \\
\text { pierwszą } \\
\text { płatwią od } \\
\text { naroża }\end{array}$} \\
\hline A1 & & & Tak/Tak & & & & \\
\hline $\mathrm{B}$ & & & Tak/Nie & & & \multirow[b]{2}{*}{$\begin{array}{l}\text { Podstawa i } \\
\text { przy } \\
\text { narożu } \\
+ \\
\text { w połowie } \\
\text { wysokości }\end{array}$} & \multirow[b]{2}{*}{$\begin{array}{l}\text { Przy narożu } \\
\text { i przy węźle } \\
\text { środk. rygla } \\
+ \\
\text { pod pierw- } \\
\text { szą płatwią } \\
\text { od naroża }\end{array}$} \\
\hline B1 & & & Tak/Tak & & & & \\
\hline $\mathrm{C}$ & & & Tak/Nie & & & \multirow[b]{2}{*}{\begin{tabular}{|l|} 
Podstawa \\
i przy \\
narożu \\
+ \\
co $1 / 3$ \\
wysokości
\end{tabular}} & \multirow[b]{2}{*}{$\begin{array}{l}\text { Przy narożu } \\
\text { i przy węźle } \\
\text { śodkowym } \\
\text { rygla } \\
+ \\
\text { pod pierw- } \\
\text { szą i drugą } \\
\text { płatwią od } \\
\text { naroża }\end{array}$} \\
\hline $\mathrm{C} 1$ & & & Tak/Tak & & & & \\
\hline $\left.\mathrm{D}^{*}\right)$ & & & Tak/Nie & & & \multirow[b]{2}{*}{$\begin{array}{l}\text { Podstawa } \\
\text { i przy } \\
\text { narożu } \\
+ \\
\text { co } 1 / 3 \\
\text { wysokości }\end{array}$} & \multirow[b]{2}{*}{$\begin{array}{l}\text { Przy narożu } \\
\text { i przy węźle } \\
\text { środkowym } \\
\text { rygla } \\
+ \\
\text { pod pierw- } \\
\text { szą, drugą } \\
\text { i trzecią } \\
\text { płatwią od } \\
\text { naroża }\end{array}$} \\
\hline D1 & & & Tak/Tak & & & & \\
\hline $\mathrm{E}$ & & & Tak/Tak & & & $\begin{array}{l}\text { Pod każdym } \\
\text { ryglem } \\
\text { ściennym }\end{array}$ & $\begin{array}{l}\text { Pod każdą } \\
\text { płatwią }\end{array}$ \\
\hline $\begin{array}{l}\text { *) Przypad } \\
\text { do któr } \\
\text { powłok }\end{array}$ & $\begin{array}{l}\text { odnic } \\
\text { ego. }\end{array}$ & jiny ra & $\begin{array}{l}\text { y analizowan } \\
\text { ki uzyskane }\end{array}$ & $N[5] n$ & odstaw & $\begin{array}{l}\text { przyjęcia mod } \\
\text { podstawie pr }\end{array}$ & $\begin{array}{l}\text { u prętowego, } \\
\text { jęcia modelu }\end{array}$ \\
\hline
\end{tabular}




\section{Wyboczenie ramy w ujęciu LBA liniowej teorii stateczności}

Przeprowadzono analizę wyboczeniową LBA w odniesieniu do wszystkich przypadków rozmieszczenia żeber oraz dyskretnych stężeń bocznych i przeciwskrętnych zestawionych w tab. 2 (przypadki A do E). W obliczeniach uwzględniono dwie kombinacje obciążeń w stanie granicznym nośności: KOMB 1 oraz KOMB 2. Jak należało się spodziewać, zastosowanie modelu powłokowego do analizy ramy o dwuteowych przekrojach blachownicowych klasy 4 pozwoliło na wykrycie interakcyjnych form utraty stateczności lokalnej (miejscowej i/lub dystorsyjnej) oraz ogólnej (giętnej lub giętno-skrętnej). Pierwszą postacią sprężystej utraty stateczności ramy jest postać lokalna i dotyczy występowania maksymalnych deformacji związanych z wybrzuszeniem smukłego środnika prawego słupa w miejscu pod narożem, którym towarzyszy giętno-skrętna niestateczność dystorsyjna środnika i pasa. Z uwagi na rzadkie rozmieszczenie żeber, co najwyżej równe odległości między ryglami ściennymi i płatwiami, nie mają one istotnego wpływu na zmianę charakteru deformacji towarzyszących pierwszej postaci wyboczenia. Rozmieszczenie stężeń też nie wpływa w istotny sposób na wartość mnożnika obciążenia krytycznego $\alpha_{c r}$ tej postaci wyboczenia. W przypadku kombinacji KOMB 1 , mnożnik $\alpha_{c r}$ pierwszej postaci wyboczenia, odpowiadający wariantom A, B, C i D, wynosi 1,55, odpowiadający wariantom A1, B1, C1, D1 i E wynosi zaś 1,58. Na rys. 6a przedstawiono pole deformacji towarzyszące mniejszemu mnożnikowi obciążenia krytycznego lokalnej utraty stateczności w odniesieniu do tej kombinacji, na rys. $6 \mathrm{~b}$ zaś dystorsję przekroju w miejscu maksymalnego wybrzuszenia środnika. Wynikowe mnożniki obciążenia krytycznego otrzymane $\mathrm{z}$ analizy numerycznej porównano z wynikami analitycznymi uzyskanymi na podstawie teorii stateczności płyt [18]. Rozważania ograniczono do górnego panelu prawego słupa ramy wydzielonego między żebrami, w którym środnik obciążono na krawędziach naprężeniami normalnymi uzyskanymi z liniowej statyki LA. W przypadku rozpatrzenia przegubowego połączenia środnika z pasami uzyskano mnożnik o wartości 0,92 (współczynnik stateczności $\mathrm{k}_{\min }=23,9$ ), a $\mathrm{w}$ przypadku sztywnego zamocowania środnika w pasach $1,52\left(\mathrm{k}_{\min }=39,6\right)$. Wynik drugiego założenia jest zgodny z mnożnikiem uzyskanym $\mathrm{z}$ analizy numerycznej.

Na rys. 7 przedstawiono dwie pierwsze formy globalnej utraty stateczności ramy $\mathrm{z}$ analizy LBA odnoszącej się do kombinacji KOMB1 oraz do modelu prętowego ramy o stężeniu $\mathrm{z}$ płaszczyzny ustroju jak w wariancie $\mathrm{D}$ oraz analizy przeprowadzonej programem ConSteel [5]. 
a)

b)

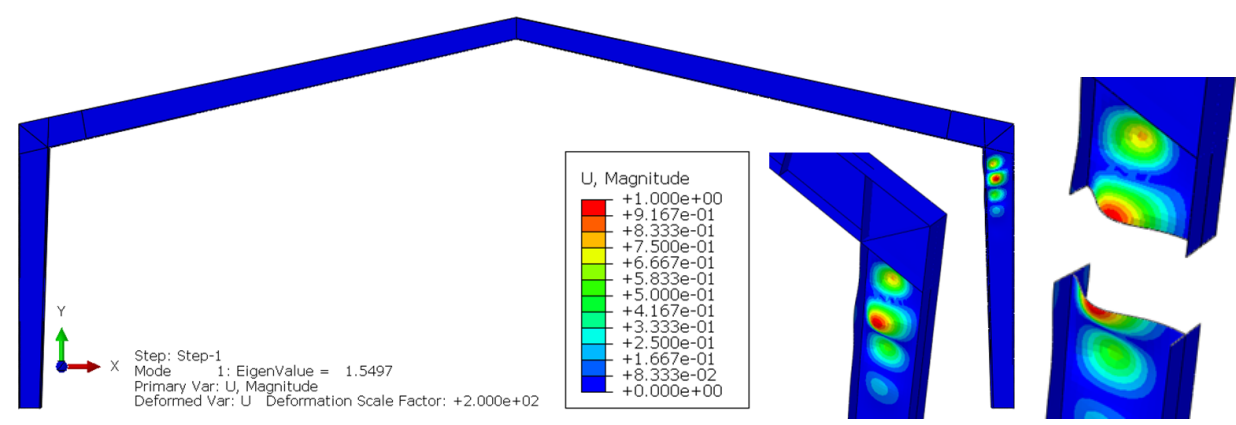

Rys. 6. Pierwsza (lokalna) postać sprężystej utraty stateczności ramy portalowej odpowiadająca mnożnikowi obciążenia krytycznego $\alpha_{c r}=1,55$, a) pole deformacji, b) dystorsja przekroju w miejscu maksymalnego wybrzuszenia środnika (współczynnik skali deformacji $=30$ )

Fig. 6. First (local) buckling mode of analyzed portal frame corresponding to critical load multiplier $\alpha_{c r}=1,55$, a) deformed shape plot, b) cross-section distortion where the web bulge reaches maximum value (deformation scale factor $=30$ )

a)

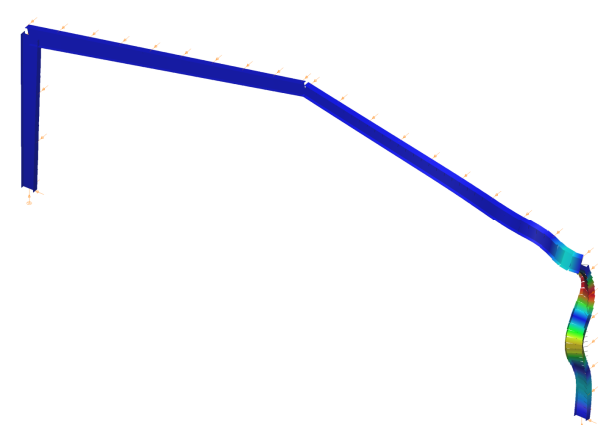

b)

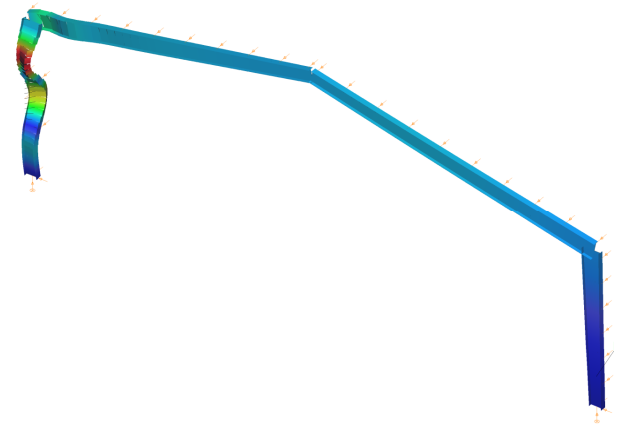

Rys. 7. Prętowe postacie wyboczenia ramy: a) postać pierwsza: nieprzechyłowa forma stowarzyszona z giętno-skrętnymi deformacjami słupa prawego $\left(\alpha_{c r, I}=11,8\right)$, b) postać druga: nieprzechyłowa forma stowarzyszona $\mathrm{z}$ giętno-skrętnymi deformacjami słupa lewego $\left(\alpha_{c r, 2}=14,8\right)$

Fig. 7. Overall buckling modes of analyzed frame: a) first mode: non-sway buckling mode corresponding to lateral-torsional deformation of the right column $\left(\alpha_{c r, l}=11,8\right)$, b) second mode: non-sway buckling mode corresponding to lateral-torsional deformation of the left column $\left(\alpha_{c r, 2}=14,8\right)$

Przeprowadzoną w niniejszej pracy analizę wartości i wektorów własnych sprężystej utraty stateczności ramy na podstawie modelu powłokowego i programu ABAQUS wariantu D stężenia ramy nie ograniczono do kilku pierwszych form utraty stateczności, ale poszukiwano form interakcyjnych lokalno-globalnych $\mathrm{w}$ celu porównania $\mathrm{z}$ wynikami uzyskanymi $\mathrm{w}$ odniesieniu do kombinacji KOMB1 oraz modelu prętowego i programu ConSteel według 
[5]. Stwierdzono, że kilkaset pierwszych form utraty stateczności jest interakcyjnych, z których trudno wyodrębnić nieprzechyłowe formy lokalnoglobalne $\mathrm{z}$ dominującą postacią globalną o charakterze wyboczenia giętnoskrętnego, jak pokazano na rys. 7a,b. Te lokalno-globalne formy niestateczności przechodzą $\mathrm{z}$ form lokalnych o dominującej składowej niestateczności miejscowej (jak na rys. 6) do form lokalnych o niestateczności dystorsyjnej, zbliżonych do interakcyjnych postaci niestateczności miejscowej i giętnoskrętnego wyboczenia ogólnego. Potwierdza to zasady projektowania przyjmowane w praktyce inżynierskiej, że giętno-skrętne formy wyboczenia traktowane są jako quasi-lokalne, a więc nie wymagające globalnej analizy LBA ustroju [19]. W konsekwencji, kryteria projektowania $\mathrm{z}$ warunku niestateczności dystorsyjnej sprawdza się na ogół jedynie w przypadku ustrojów złożonych z kształtowników giętych [20], a w wypadku kształtowników walcowanych i blachownic spawanych uwzględnia się jedynie interakcję niestateczności miejscowej i niestateczności ogólnej [21]. Parametry stanu krytycznego giętno-skrętnego wyboczenia elementów ram ocenia się tradycyjnie $\mathrm{z}$ analizy pojedynczego elementu ramy wydzielonego usztywnieniami przeciwskrętnymi, lub $\mathrm{z}$ analizy podukładu konstrukcji $\mathrm{z}$ uwzględnieniem efektu interakcji segmentów wydzielonych stężeniami przeciwskrętnymi (por. [22]). Należy natomiast zwrócić bardzo dużą uwagę na interakcję niestateczności miejscowej i globalnej w formie przechyłowej, które wciągają do współpracy wszystkie elementy ustroju nośnego (jak na rys. 8b).

Analiza sprężystej utraty stateczności w ujęciu modelu powłokowego wykazała, iż występuje wiele interakcyjnych form przechyłowych sprzężonych z lokalnymi formami wyboczenia prętów pasów ramy. W przypadku kombinacji KOMB1 i wariantu D, pierwszą taką postacią jest forma $\mathrm{nr} 1172$, o mnożniku obciążenia krytycznego $\alpha_{c r, 1172}=14,6$, podczas gdy w ujęciu teorii prętowej jest trzecią o mnożniku $\alpha_{c r, 3}=16,8$ (rys. 8a) [5]. W ujęciu teorii powłok, największy składnik niestateczności lokalnej pasów prętów ramy zawiera 1251. forma $\left(\alpha_{c r, 125 l}=15,4\right)$, a najmnijeszy postać $\mathrm{nr} 1362$ $\left(\alpha_{c r, 1362}=16,5\right.$, wg rys. 8 b), która jest najbliższa globalnej formie uzyskanej $\mathrm{z}$ zastosowania teorii prętowej.

Sprzężenie form wyboczenia ogólnego o postaci przechyłowej oraz lokalnego o postaci miejscowej utraty stateczności jest niebezpieczne z punktu widzenia projektowania stalowych ustrojów ramowych i powinno być uwzględniane w projektowaniu, niezależnie od tego, czy forma przechyłowa jest jedną z pierwszych, czy też formą dość odległą od pierwszych postaci lokalnych form utraty stateczności. 
a)

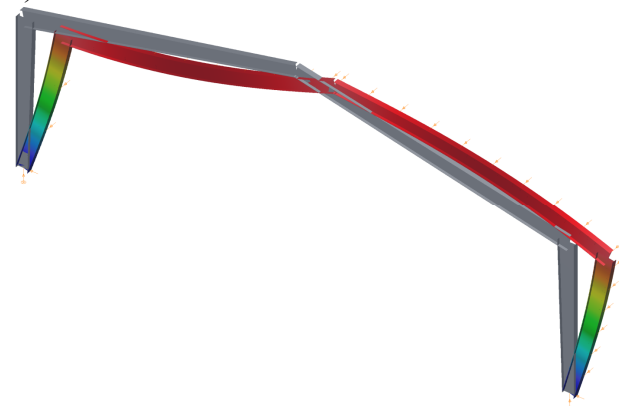

b)

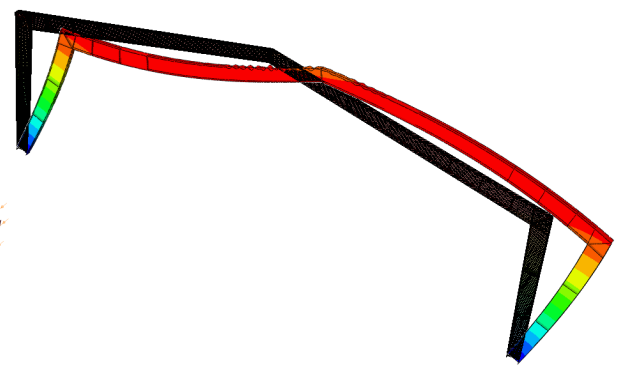

Rys. 8. Przechyłowe formy wyboczenia ramy (na tle układu nieodkształconego): a) giętna forma w ujęciu teorii prętowej, b) interakcyjna forma w ujęciu teorii powłokowej

Fig. 8. Sway buckling modes of analyzed frame (on the background of undeformed shape plot): a) lateral form in terms of beam theory, b) interactive sway form in terms of plate theory

\section{Nośność ramy w ujęciu GMNA i GMNIA technicznej utraty stateczności}

Analizy GMNA przeprowadzono w odniesieniu do idealnej geometrii ramy oraz jak nazwa wskazuje z uwzględnienieniem geometrycznej i metriałowej nieliniowości. Stan graniczny ramy identifikowano z punktem granicznym na ścieżce równowagi opisujacej mnożnik obciążenia granicznego $\alpha_{u l t} \mathrm{~W}$ zależności od tzw. przemieszczenia wiodącego (w przypadku kombinacji KOMB1 jest to przemieszczenie pionowe węzła kalenicowego, w przypadku KOMB2 zaś przemieszczenie poziome węzła okapowego). W wypadku, gdy stan graniczny ramy związany jest $\mathrm{z}$ wytężeniem przekrojów poniżej granicy plastyczności, punkt graniczny wyznacza jednoznacznie stan naprężenia w przekrojach elementów ramy, a więc największego naprężenia zastępczego wg hipotezy Hubera-Misesa $\sigma_{e, H-M} \mathrm{~W}$ najbardziej wytężonym przekroju jego najbardziej wytężonego elementu, co daje $\alpha_{u l t}=f_{y} / \sigma_{e, H-M}$. Na podstawie uzyskanych wyników można wyciągnąć podobne wnioski, jak w przypadku analizy sprężystej utraty stateczności. Mnożniki obciążenia granicznego w wypadku kombinacji KOMB2 są niższe o ok. $5 \% \mathrm{w}$ porównaniu $\mathrm{z}$ otrzymanymi w wypadku KOMB1, a więc o ocenie bezpieczeństwa ramy decyduje kombinacja „grawitacyjna”. W wariantach usztywnienia elementów ramy A, B, C i D uzyskano praktycznie taki sam mnożnik obciążenia granicznego jak w pozostałych wariantach (mnożnik $\alpha_{u l t}=1,12$ ), co wskazuje na fakt, że nośność ram portalowych o przekrojach smukłościennych silnie zależy od lokalnych form niestateczności (identyfikowanych z nośnością przekroju klasy 4), a nie globalnych form niestateczności ram, opisywanych interakcyjnymi kryteriami stateczności ogólnej jej elementów. Na rys. 9 przedstawiono wyniki analizy dotyczacej wariantu D i kombinacji KOMB1, zarówno ścieżkę równowagi 
ramy jak i mapę naprężeń w obszarze największego wytężenia jej przekrojów. W przypadku identyfikowania mnożnika obciążenia granicznego z punktem granicznym na ścieżce równowagi (gdy dopuszcza się uplastycznienie więcej niż jednego elementu ramy), uzsykano wartość tego mnożnika $\alpha_{u l t}=1,60$.

a)

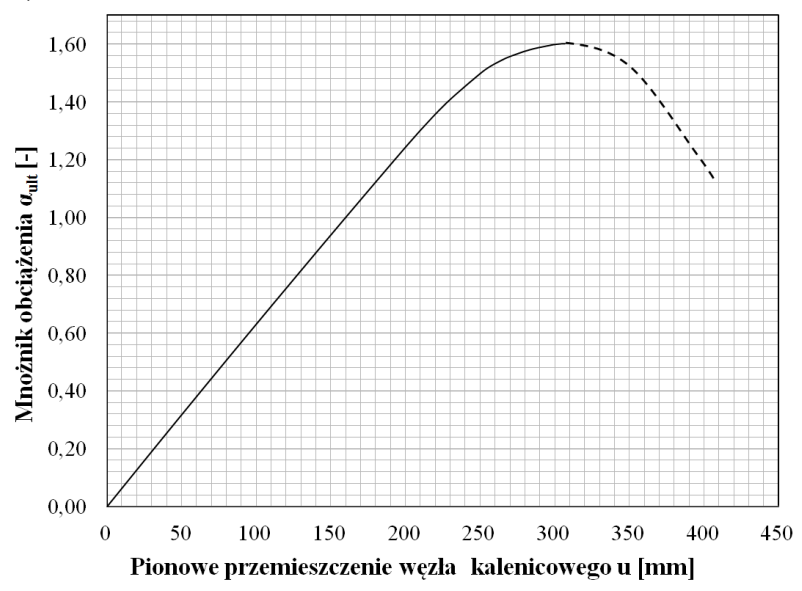

b)

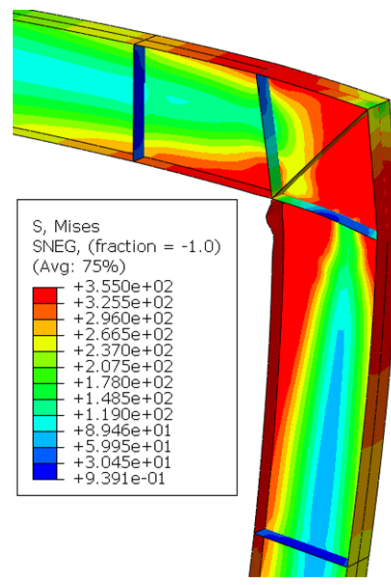

Rys. 9. Wyniki analizy GMNA: a) ścieżka równowagi, b) mapa warstwicowa naprężeń zastępczych Hubera-Misesa w punkcie granicznym ścieżki równowagi (współczynnik skali deformacji $=10$ )

Fig. 9. Results of GMNA: a) load-deformation-curve, b) Huber-Mises stresses at limit point of loading path (deformation scale factor $=10$ )

W przypadku analizy GMNIA, geometrię elementu imperfekcyjnego w konfiguracji początkowej przyjęto jako przeskalowaną postać sprężystej utraty stateczności ramy, rozróżniając postacie lokalne oraz lokalno-globalne. W wypadku przyjęcia pierwszej, lokalnej postaci wyboczenia, imperfekcyjna geometria ramy dotyczy deformacji odpowiadających miejscowej formie niestateczności. Wartość współczynnika skalującego dotyczy wówczas wartości maksymalnej rzędnej wybrzuszenia smukłego środnika prawego słupa ramy (por. rys. 6). Parametr skalujący odniesiono do wartości $e_{0}=1 / 200 a$, gdzie $a-$ mniejszy z wymiarów panelu środnika $\mathrm{w}$ miejscu wybrzuszenia, tj. około $1060 \mathrm{~mm} / 200=5,3 \mathrm{~mm}$, gdzie $1060 \mathrm{~mm}$ to wysokość środnika. Największe naprężenie zastępcze występuje $\mathrm{w}$ prawym słupie pod narożem i wynosi $318 \mathrm{~N} / \mathrm{mm}^{2}$, co daje mnożnik obciążenia granicznego $\alpha_{u l t}=1,11$ (w wypadku, gdy stan graniczny ramy związany jest $\mathrm{z}$ wytężeniem przekrojów poniżej granicy plastyczności). Naprężenie to jest większe o ok. $4 \mathrm{~N} / \mathrm{mm}^{2}$ w stosunku do uzyskanego z analizy GMNA układu o geometrii idealnej. Uzyskane wyniki porównano na rys. 10 . 

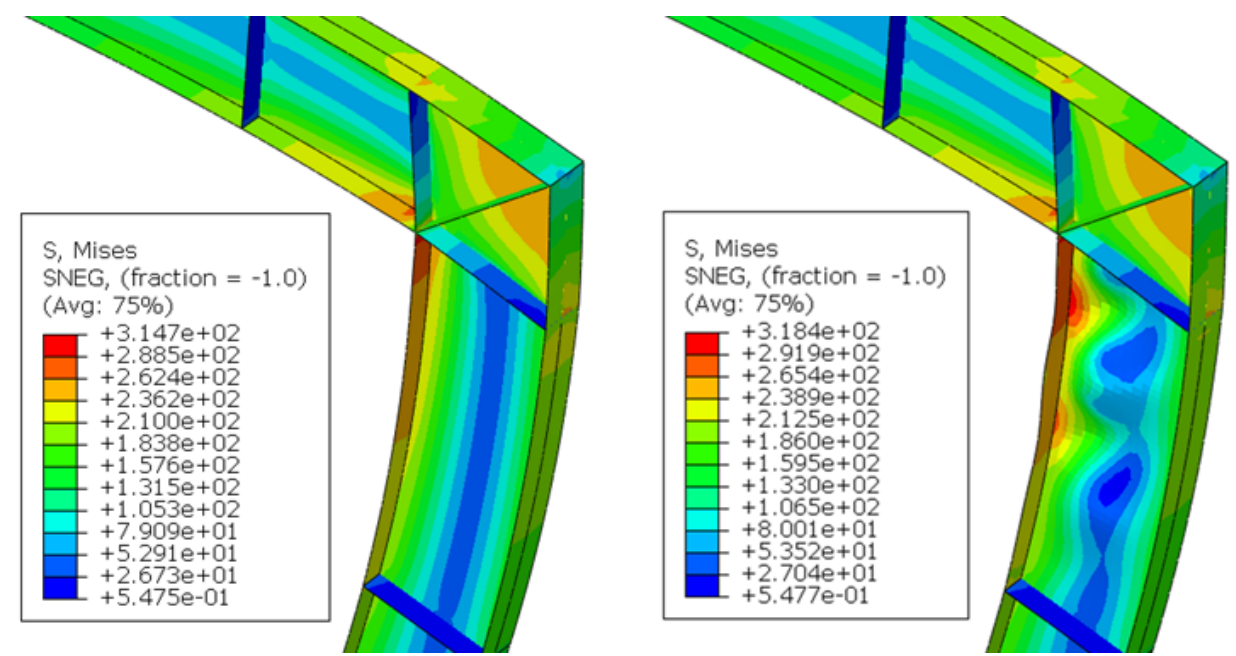

Rys. 10 Mapa warstwicowa naprężeń zastępczych Hubera-Misesa na końcu kroku obliczeniowego w przypadku analizy: a) GMNA, b) GMNIA (współczynnik skali deformacji = 30)

Fig. 10 Huber-Mises stresses at the end of step time in the case of: a) GMNA, b) GMNIA (deformation scale factor $=10$ )

a)

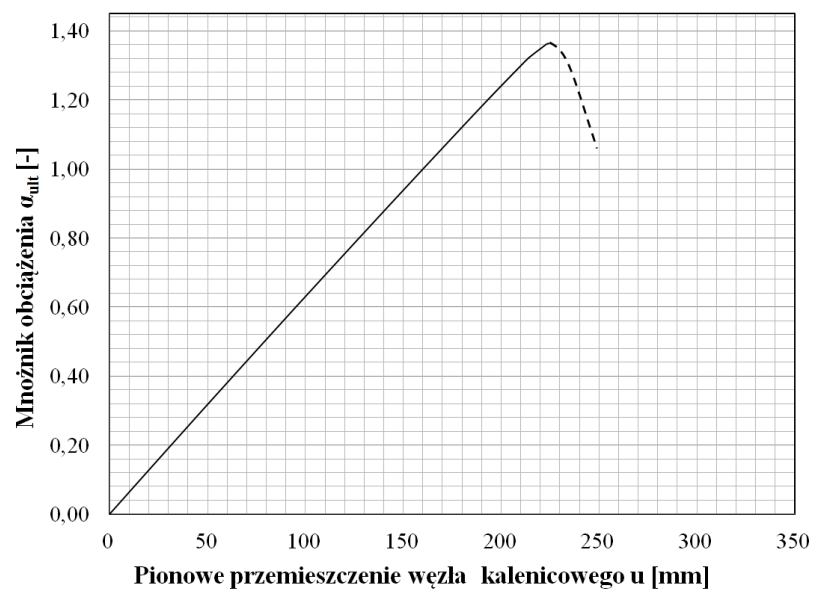

b)

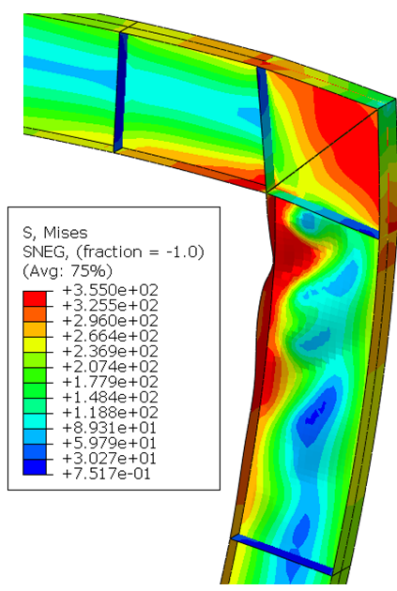

Rys. 11. Wyniki analizy GMNIA, a) ścieżka równowagi, b) mapa warstwicowa naprężeń zastępczych Hubera-Misesa w punkcie granicznym ścieżki równowagi (współczynnik skali deformacji $=10$ )

Fig. 11. Results of GMNIA: a) load-deformation-curve, b) Huber-Mises stresses at limit point of loading path (deformation scale factor $=10$ )

$\mathrm{Na}$ rys. 11 przedstawiono ścieżkę równowagi ramy i mapę naprężeń w obszarze największego wytężenia jej przekrojów. W przypadku identyfikowania mnożnika obciążenia granicznego z punktem granicznym na 
ścieżce równowagi (gdy dopuszcza się uplastycznienie więcej niż jednego elementu ramy), uzsykano wartość tego mnożnika $\alpha_{u l t}=1,36$. W sytuacji implementacji imperfekcji stowarzyszonej z globalną formą przechyłową ramy (parametr skalujący odniesiono do przechyłu narożnika ramy, którego wartość przyjęto jako $1 / 200$ wysokości słupa) uzyskano mnożnik $\alpha_{u l t}=1,58$, a w przypadku liniowej kombinacji imperfekcji lokalnej i globalnej przechyłowej $\alpha_{u l t}=1,35$.

Jak już wspomniano poprzednio, w wypadku ram o prętach klasy 4, w modelu imperfekcyjnym należy uwzględnić formy interakcyjne lokalnoglobalne $\mathrm{w}$ postaci przechyłowej, oprócz form lokalnych. Zgodnie z załacznikiem B normy [9], wartość amplitudy imperfekcji form lokalnoglobalnych wynosi, po przyjęciu $\gamma_{M I}=1,0$ :

$$
\frac{1-\frac{\rho \bar{\lambda}}{\gamma_{M 1}}}{1-\rho \bar{\lambda} p}=\alpha_{p}\left(\bar{\lambda}_{p}-\bar{\lambda}_{p 0}\right) \frac{t}{6}
$$

gdzie względną smukłość $\bar{\lambda}_{p}$ oblicza się jak niżej:

$$
\bar{\lambda}_{p}=\sqrt{\frac{\alpha_{u l t}}{\alpha_{c r}}}
$$

Progowa wartość smukłości względnej w odniesieniu do kształtownika spawanego wynosi $\bar{\lambda}_{p 0}=0,70$ (dominacja naprężeń ściskających), parametr imperfekcji przyjmuje się natomiast jak dla krzywej wyboczeniowej $b$, tzn. $\alpha_{p}=0,34$. Mnożnik obciążenia granicznego $\alpha_{u l t}$ uzyskuje się z analizy MNA I rzędu (bez uwzględnienia efektów stateczności miejscowej i ogólnej, wg rys. 12), a mnożnik obciążenia krytycznego $\alpha_{c r}$, przy którym element osiąga stan krytyczny ze względu na niestateczność miejscową lub zwichrzenie, oblicza się na podstawie analizy wyboczeniowej LBA. Uwzględniając kombinację KOMB1 otrzymano:

$$
e_{0}=\alpha_{p}\left(\bar{\lambda}_{p}-\bar{\lambda}_{p 0}\right) \frac{t}{6}=0,34 \cdot\left(\sqrt{\frac{1,86}{1,55}}-0,70\right) \cdot \frac{8}{6}=0,18 \mathrm{~mm}<\frac{1060}{200}=5,3 \mathrm{~mm} .
$$

Uzyskana wartość amplitudy imperfekcji jest mniejsza, niż ta wynikająca z postanowień załącznika C normy [9]. Nie uwzględniono jej zatem w obliczeniach. 


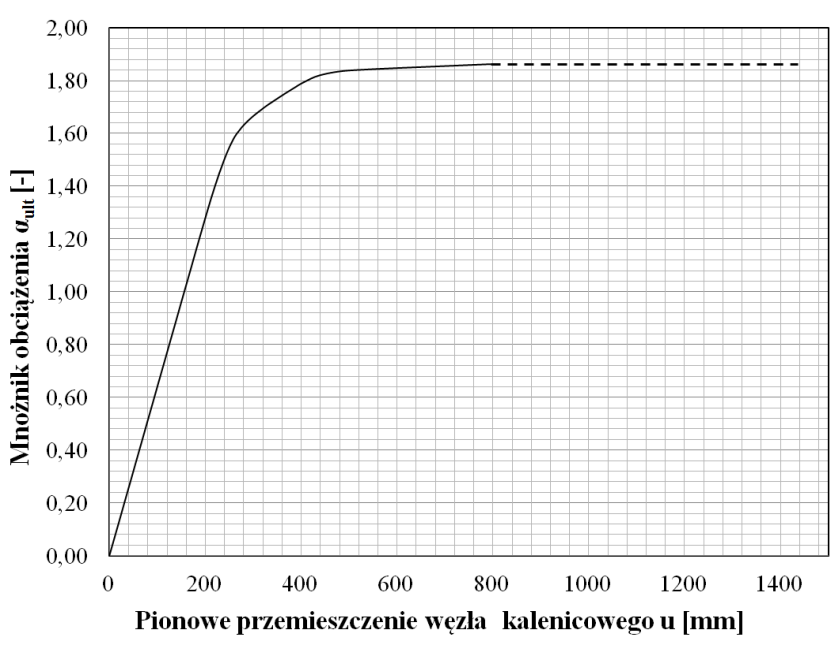

Rys. 12. Ścieżka równowagi w przypadku liniowej analizy MNA, $\alpha_{u l t}=1,86$

Fig. 12. Load-deformation-curve in the case of MNA, $\alpha_{u l t}=1,86$

\section{Wnioski}

W przypadku obliczania stalowych ram portalowych dopuszcza się stosowanie sprężystych oraz niesprężystych metod analiz z wykorzystaniem teorii prętowej lub powłokowej. Niemniej jednak, każdorazowy wybór metody powinien być racjonalnie uzasadniony. W pracy [5], do obliczeń przyjęto prętowy model MES ramy z elementami belkowymi spełniającymi założenia teorii prętów cienkościennych Własowa oraz analizę materiałowo liniową. W niniejszym artykule rozszerzono te badania o zastosowanie nieliniowości materiału oraz przyjęcie powłokowego modelu MES konstrukcji. Na podstawie przeprowadzonych analiz (LBA, MNA, GMNA, GMNIA) ramy portalowej o smukłościennych elementach blachownicowych można wyciągnąć następujące wnioski:

- model powłokowy pozwala uzyskać zarówno lokalne jak i globalne postaci sprężystej utraty stateczności ramy (oraz ich kombinacje). Uproszczenia modelu prętowego prowadzą do uzyskania tylko postaci globalnych wyboczenia układu,

- rzadkie rozmieszczenie żeber, co najwyżej równe odległości między ryglami ściennymi lub płatwiami, nie ma istotnego wpływu na zmianę charakteru deformacji towarzyszących pierwszej postaci wyboczenia,

- analiza postaci wyboczenia sprężystego ramy (form lokalno-globalnych, dystorsyjnych, zbliżonych do interakcyjnych postaci niestateczności miejscowej i giętno-skrętnego wyboczenia ogólnego) potwierdza zasady projektowania przyjmowane w praktyce inżynierskiej, że giętno-skrętne formy wyboczenia traktowane są jako quasi-lokalne, a więc nie wymagające globalnej analizy LBA ustroju, 
- należy zwrócić bardzo dużą uwagę na interakcję niestateczności miejscowej i globalnej w formie przechyłowej, które wciągają do współpracy wszystkie elementy ustroju nośnego,

- implementacja imperfekcji wstępnych stowarzyszonych z pierwszą lokalną utratą stateczności ramy (wybrzuszenie środnika słupa prawego w miejscu pod narożem) nie zwiększa istotnie wytężenia konstrukcji. Różnica pomiędzy wynikami analiz GMNA i GMNIA wynosi około 1\% w odniesieniu do wartości granicy plastyczności,

- za słuszne uznaje się uproszczenie normy [8], że w przypadku przechyłowych ram portalowych można stosować w obliczeniach statycznych analizę pierwszego rzędu bez imperfekcji. Weryfikacja nośności słupa bądź rygla pełnościennej ramy portalowej sprowadza się wtedy do analizy pręta ściskanego mimośrodowo i uwzględnienia interakcji niestateczności lokalnej i ogólnej, odpowiadającej formom giętnym oraz giętno-skrętnym.

\section{Literatura}

[1] Biegus A.: Stalowe budynki halowe. Arkady, Warszawa 2008.

[2] Mendera Z., Kuchta K.: Przykłady wymiarowania konstrukcji stalowych z profili SIN. Wydawnictwo Politechniki Krakowskiej 2003.

[3] Bródka J.: Stalowe konstrukcje hal i budynków wysokich, t.1, Wyd. Politechniki Łódzkiej, Łódź 1994.

[4] Kozłowski A., Ostrowski K.: Kształtowanie i obliczanie ram portalowych według PN-EN 1993-1-1. "Inżynieria i Budownictwo", nr 7/2009.

[5] Stachura Z., Giżejowski M.: Eurokodowe procedury statecznościowego sprawdzania nośności ram płaskich. 61 Konferencja Naukowa Komitetu Inżynierii Lądowej i Wodnej PAN oraz Komitetu Nauki PZITB „Bydgoszcz - Krynica 2015”.

[6] Weiss S., Giżejowski M.: Stateczność konstrukcji metalowych. Układy prętów. Arkady, Warszawa 1991.

[7] Biegus A.: Nośność graniczna stalowych konstrukcji prętowych. Wydawnictwo Naukowe PWN. Warszawa-Wrocław 1997.

[8] PN-EN 1993-1-1: Eurokod 3 - Projektowanie konstrukcji stalowych. Część 1-1: Reguły ogólne i reguły dla budynków.

[9] PN-EN 1993-1-5: Eurokod 3 - Projektowanie konstrukcji stalowych. Część 1-5: Blachownice.

[10] PN-EN 1993-1-6: Eurokod 3 - Projektowanie konstrukcji stalowych. Część 1-6: Wytrzymałość i stateczność konstrukcji powłokowych.

[11] PN-EN 1993-1-7: Eurokod 3 - Projektowanie konstrukcji stalowych. Część 1-7: Konstrukcje plytowe.

[12] Giżejowski M., Barszcz A., Ślęczka L.: Ogólne zasady projektowania stalowych układów ramowych według PN-EN 1993-1-1. "Inżynieria i Budownictwo", nr 7/2009.

[13] Steel buildings in Europe. Single story buildings. CTICM, SCI, 2008 (http://www.arcelormittal.com/sections/pl/biblioteka/design-manualssteelbuildings-in-europe.html [dostęp: 8 maja 2015 r.]). 
[14] Simoes da Silva L., Simoes R., Gervasio H.: Design of Steel Structures, Eurocode 3: Design of steel structures, Part 1-1: General rules and rules for buildings. ECCS Eurocode Design Manual, Ernst \& Sohn, 2010.

[15] ABAQUS Theory Manual, Version 6.11, Dassault Systèmes, 2011.

[16] ABAQUS/Standard User's manual, Version 6.1., Hibbitt, Karlsson and Sorensen, Inc., Pawtucket, 2000

[17] Jemioło S., Gajewski M.: Hipersprężystoplastyczność, Seria wydawnicza Monografie Zakładu Wytrzymałości Materiałów, Teorii Sprężystości i Plastyczności, Tom III, OWPW, 2014.

[18] Rykaluk K.: Zagadnienia stateczności konstrukcji metalowych, Dolnośląskie Wydawnictwo Edukacyjne, Wrocław 2012

[19] Bródka J., Barszcz A., Giżejowski M., Kozłowski A.: Nośność i sztywność stalowych ram przechyłowych o węzłach podatnych. Oficyna Wydawnicza Politechniki Rzeszowskiej, Rzeszów 2004.

[20] Hancock G. J., Murray T. M., Ellifritt D. S.: Cold-Formed Structures to the AISI Specification. Marcel Dekker, Inc., New York 2001.

[21] Kubieniec G., Piekarczyk M.: Peculiar problems of the post-buckling behaviour of thin-walled steel girders and columns. Archives of Civil Engineering, Vol. 53, nr 2, 2007.

[22] Trahair N.S.: Flexural-Torsional Buckling of Structures. CRC Press, Boca Raton 1993.

\section{RESISTANCE ASSESSMENT OF STEEL PLANAR FRAME FABRICATED FROM SLENDER WEB PLATE GIRDERS}

\section{S u m m a r y}

An assessment of the load bearing capacity analysis of steel planar frame fabricated from slender tapered plate girders, with span length of $36,0 \mathrm{~m}$ and pinned bases was presented in the paper. Initially, considered portal frame was designed in accordance with the Eurocode 3 and then an influence of lateral and torsional braces location on the frame load bearing capacity was analyzed. Calculations take into account imperfections of the structure, which were implemented in the FEM model as local and global scaled modes derived from linear buckling analysis LBA. In order to investigate the effect of type and shape of particular imperfection patterns on the frame stability strength, two tasks were solved. Firstly, geometrically and materially nonlinear analysis GMNA of perfect frame geometry was carried out. Then, GMNIA analysis concerning additionally imperfections was performed. Numerical models were prepared with the use of shell finite elements, which are available in ABAQUS/Standard program. Concluding remarks were drawn.

Keywords: portal frame, steel plate girders, stability, imperfections, LBA, GMNA, GMNIA

Przestano do redakcji:30.05.2015

Przyjęto do druku:10.01.2016

DOI: $10.7862 / \mathrm{rb} .2015 .179$ 